\title{
PENGEMBANGAN SUMBER DAYA MANUSIA BIDANG PENDIDIKAN
}

\section{Oleh: Epon Ningrum*)}

\begin{abstract}
Abstrak
Sumber daya manusia (SDM) menjadi faktor dominan dalam suatu institusi, tidak terkecuali pada bidang pendidikan. Pendidikan memerlukan SDM berkualitas untuk melaksanakan perannya dalam melayani kebutuhan pendidikan masayarakat. Kebutuhan pendidikan tersebut meliputi kebutuhan yang bersifat praktis situasional maupun bersifat prediktif antisipatif bagi transformasi sosial. Untuk itu, sangat penting upaya pengembangan SDM bagi terwujudnya SDM bidang pendidikan yang berkualitas.

Pengembangan SDM dilakukan melalui pendidikan dan pelatihan, baik secara formal maupun informal, yang dilaksanakan secara simultan berkelanjutan. Terdapat lima domain SDM yang dipandang penting dalam pengembangan SDM bidang pendidikan. Kelima domain tersebut adalah: profesionalitas, daya kompetitif, kompetensi fungsional, keunggulan partisipatif, dan kerja sama. Namun demikian, pengembangan terhadap kelima domain SDM tersebut diperlukan total quality qontrol (TQC) dan program diklat terpadu agar tercapai efektivitasnya.
\end{abstract}

Kata kunci: pengembangan, sumber daya manusia, pendidikan, profesionalitas, daya kompetitif, kompetensi fungsional, keunggulan partisipatif.

\section{Pendahuluan}

Pendidikan diyakini sebagai salah satu bidang yang memiliki peran penting dan strategis dalam pembangunan suatu bangsa. Bahkan menjadi faktor dominan di dalam proses peningkatan kecerdasan bangsa. Betapa penting dan strategis peranan pendidikan di dalam pembangunan bangsa, hal tersebut telah diakuai sejak dirumuskannya UUD 1945. Tanpa bangsa yang cerdas tidak mungkin bangsa itu ikut serta dalam percaturan global.

Secara umum, terdapat dua orientasi pendidikan dalam pembangunan bangsa, yaitu orientasi individual dan orientasi masyarakat. Orientasi individual, pendidikan berperan dalam pembentukan insan terdidik (educated person) yaitu melalui proses pengembangan potensi diri. Kemampun yang dimiliki oleh insan terdidik merupakan sarana bagi pemahaman diri dan lingkungan, upaya adaptasi dan partisipasi dalam perubahan, pelaku utama bagi perubahan (inovator), dan memiliki orientasi prediktif dan antisipatif. Dengan demikian, manusia terdidik dapat menjadi anutan bagi yang lainya (reference behavior) dan memiliki andil dalam membangun masyarakat (society building). Untuk itu, manusia terdidik harus memiliki keunggulan partisipatif bagi terwujudnya transformasi sosial yang menyeluruh.

Sedangkan orientasi masyarakat, pendidikan memiliki tiga peran utama yakni sebagai agen konservatif (agent of conservation), agen inovatif (agent of

*) Dr. Epon Ningrum, M.Pd., adalah dosen Jurusan Pendidikan Geografi FPIPS-UPI. 
innovation), dan agen perubahan (agent of change). Sebagai agen konservatif, pendidikan secara operasional praktis melalui kegiatan pembelajaran yang berorientasi pada penanaman dan pelestarian nilai-nilai sosial-budaya asli (indigeneous) yang memiliki ketangguhan dan ketahanan (homeostatic). Dengan demikian, masyarakat akan memiliki jati diri dalam menyikapi arus globalisasi.

Sebagai agen inovatif, pendidikan memiliki peran dalam mengembangkan ilmu pengetahuan, mendesiminasikan, mensosialisasikan, dan mengaplikasikannya. Melalui perannya tersebut, pendidikan akan menghasilkan masyarakat pembelajar (learning society) yang diekspresikan dengan gemar mencari informasi, menggunakan, dan mengkomunikasikannya. Sedangkan sebagai agen perubahan, pendidikan memiliki konsekuensi terhadap aplikasi dari produk inovasi pendidikan, sehingga pendidikan menjadi katalisator bagi terjadinya transformasi sosial. Pendidikan tidak hanya berorientasi pada masa sekarang, melainkan bersifat dinamis dan antisipatif bagi terjadinya perubahan.

Dengan beberapa peran yang dimilikinya tersebut, pendidikan dituntut memiliki sumber daya pendidikan untuk mempersiapkan pelaku-pelaku perubahan yang tangguh, unggul, partisipatif, dan kompetitif. Sumber daya pendidikan adalah segala sesuatu yang dipergunakan dalam penyelenggaraan pendidikan yang meliputi tenaga kependidikan, masyarakat, dana, sarana, dan prasarana (UURI No. 20 Tahun 2003). Selanjutnya dinyatakan bahwa tenaga kependidikan adalah anggota masyarakat yang mengabdikan diri dan diangkat untuk menunjang penyelenggaraan pendidikan. Selanjutnya, dalam pembahasan ini, tenaga kependidikan dipakai istilah sumber daya manusia pada bidang pendidikan.

Mengingat peran penting dan strategis bidang pendidikan, maka pengembangan sumber daya manusia pada bidang ini menjadi tuntutan, baik tuntutan yuridis formal dan teknis operasionalnya maupun tuntutan penguasaan teoretis dan praktik empiris. Pertanyaannya adalah bagamana pengembangan sumber daya manusia yang berorientasi pada peningkatan kualitas dan ketercapaian tujuan pendidikan nasional?

\section{Pembahasan}

Pengembangan dan pendidikan merupakan dua konsep yang berbeda, tetapi memiliki keterkaitan yang saling mempengaruhi satu sama lain. Dalam konstelasi tulisan ini, pengembangan dapat dilakukan melalui pendidikan, sehingga pendidikan menjadi wahana bagi pengembangan. Untuk itu, maka pendidikan memerlukan SDM yang kompeten sebagai aset bagi proses pengembangan dan SDM yang kompeten tersebut dicapai melalui proses pengembangan. Dengan demikian, SDM menjadi bagian penting dalam pengembangan dan pendidikan.

Pendidikan merupakan suatu sistem yang terdiri atas komponen-komponen saling yang saling terkait secara fungsional bagi tercapainya pendidikan yang berkualitas. Setidaknya terdapat empat komponen utama dalam pendidikan, yaitu: SDM, dana, sarana, perasarana, dan kebijakan. Komponen SDM dapat dikatakan menjadi komponen strategis, karena dengan SDM berkualitas dapat 
mendayagunakan komponen lainnya, sehingga tercapai efektivitas dan efisiensi pendidikan. Di mana SDM berkualitas dapat dicapai dengan pengembangan SDM.

Pengembangan adalah upaya meningkatkan sesuatu agar lebih bertambah baik. Pengembangan SDM dapat dilakukan melalui pendidikan dan latihan. Seperti dikemukakan Sikula (1981: 38):

development in reference to staffing and personnel matters, is a long term educational process utilizing a systematic and organized procedure by which managerial personel learn conceptual and theoetical knowledge for general purpuses. Training is a short term educational process utilizing a systematic and orgenized procedure by which nonmanagerial personnel learn technical knowledge and skill for a definite purpose.

Selain itu, Hasibuan (2007: 69) mengemukakan bahwa pengembangan adalah suatu usaha untuk meningkatkan kemampuan teknis, teoretis, konseptual, dan moral karyawan sesuai dengan kebutuhan pekerjaan/jabatan melalui pendidikan dan latihan. Sedangkan menurut Bella, pendidikan dan latihan sama dengan pengembangan yaitu merupakan proses peningkatan keterampilan kerja, baik secara teknis maupun manajerial. Dimana, pendidikan berorientasi pada teori dan berlangsung lama, sedangkan latihan berorientasi pada praktek dengan waktu relatif singkat.

Pendidikan adalah usaha sadar dan terencana untuk mewujudkan suasana belajar dan proses pembelajaran agar peserta didik secra aktif mengembangkan potensi dirinya untuk memiliki kekuatan spiritual keagamaan, pengendalian diri, kepribadian, kecerdasan, akhlak mulia, serta keterampilan yang diperlukan dirinya, masyarakat, bangsa dan negara (UURI No. 20 Th. 2003: 2). Sedangkan latihan, secara implisit menjadi bagian dari pendidikan.

SDM adalah kemampuan terpadu dari daya pikir dan daya fisik yang dimiliki individu (Hasibuan, 2007:243). Selanjutnya dijelaskan bahwa daya pikir adalah kecerdasan yang dibawa lahir (modal dasar) sedangkan kecakapan adalah diperoleh dari usaha pendidikan. Daya fisik adalah kekuatan dan ketahanan seseorang untuk melakukan pekerjaan atau melaksanakan tugas yang diembannya. Dengan demikian, SDM bidang pendidikan adalah kompetensi fungsional yang dimiliki tenaga kependidikan dalam melaksanakan tugasnya.

Di dalam melaksanakan tugasnya, SDM dituntut mengaktualisasikan kemampuannya, baik daya fikir maupun daya fisik secara terintagrasi. Namun demikian, kedua kemampuan tersebut saja tidak cukup, melainkan harus diimbangi dengan kecerdasan emosional (Emotional Intellegence). Manakala kita memandang duni pekerjaan adalah sebagai suatu masyarakat, maka kecerdasan emosional sangat diperlukan untuk mengenal dan memahami diri sendiri serta rekan kerja. Menurut Goleman (1996), kecerdasan emosional memiliki keunggulan dibandingkan kecerdasan intelektual, jika dasar penentunya adalah keberhasilan hidup di tengah masyarakat. 
SDM yang berkualitas yang dibutuhkan diperoleh melalui proses, sehingga dibutuhkan suatu program pendidikan dan pelatihan untuk mempersiapkan dan pengembangan kualitas SDM yang sesuai dengan transformasi sosial. Menurut Tilaar (1998), terdapat tiga tuntutan terhadap SDM bidang pendidikan dalam era globalisasi, yaitu: SDM yang unggul, SDM yang terus belajar, dan SDM yang memiliki nilai-nilai indigeneous. Terpenuhinya ketiga tuntutan tersebut dapat dicapai melalui pengembangan SDM.

Dalam upaya pengembangan SDM hendaknya berdasarkan kepada prinsip peningkatan kualitas dan kemampuan kerja. Terdapat beberapa tujuan pengembangan SDM, di antaranya adalah: (1) meningkatkan kompetensi secara konseptual dan tehnikal; (2) meningkatkan produktivitas kerja; (3) meningkatkan efisiensi dan efektivitas; (4) meningkatkan status dan karier kerja; (5) meningkatkan pelayanan terhadap klient; (6) meningkatkan moral-etis; dan (7) meningkatkan kesejahteraan.

Berdasarkan penuturan Hasibuan (2007: 72-73), terdapat dua jenis pengembangan SDM, yaitu: pengembangan SDM secara formal dan secara informal. Pertama, pengembangan SDM secara formal yaitu SDM yang ditugaskan oleh lembaga untuk mengikuti pendidikan atau latihan, baik yang dilaksanakan oleh lembaga tersebut maupun lembaga diklat. Pengembangan SDM secara formal dilakukan karena tuntutan tugas saat ini maupun masa yang akan datang. Dengan demikian, jenis pengembangan ini dapat memenuhi kebutuhan kompetensi SDM yang bersifat empirical needs dan predictive needs bagi eksistensi dan keberlanjutan lembaga.

Kedua, pengembangan SDM secara informal yaitu pengembangan kualitas SDM secara individual berdasarkan kesadaran dan keinginan sendiri untuk meningkatkan kualitas diri sehubungan dengan tugasnya. Banyak cara yang dapat dilakuklan SDM untuk meningkatkan kemampuannya, namun jenis pengembangan ini memerlukan motivasi intrinsik yang kuat dan kemampuan mengakses sumbersumber informasi sebagai sumber belajar.

Terdapat lima domain penting dalam pengembangan SDM bidang pendidikan, yaitu: profesionalitas, daya kompetitif, kompetensi fungsional, keunggulan partisipatif, dan kerja sama. Dimilikinya kemampuan terhadap kelima domain tersebut merupakan modal utama bagi SDM dalam menghadapi masyarakat ilmu (Knowledge Society) yang dinamis. Asumsi yang mendasari pentingnya kelima domain tersebut adalah sebagai berikut.

a Profesionalitas

Profesionalitas adalah tingkatan kualitas atau kemampuan yang dimiliki SDM dalam melaksanakan profesinya. Sedangkan profesionalisme adalah penyikapan terhadap profesi dan profesionalitas yang dimilikinya. SDM yang profesional adalah mereka yang memiliki keahlian dan keterampilan melalui proses pendidikan dan latihan. 
Kemampuan tersebut meliputi kemampuan teknik dan kemampuan konseptual dalam memberikan layanan formal sesuai dengan profesi dan keahliannya. Berdasarkan kemampuan SDM dalam melaksanakan tugasnya tersebut, maka masyarakat akan mengakui dan menghargainya. Dengan kata lain, penghargaan dan pengakuan masyarakat bergantung kepada keprofesionalan SDM.

Pengakuan masyarakat terhadap suatu profesi bersifat merit, sehingga menuntut SDM yang berkualitas. SDM bidang pendidikan, mereka bekerja dalam suatu masyarakat profesional (profesional community) yang menuntut kejujuran profesional agar dapat memberikan layanan profesi sesuai dengan harapan masyarakat. Namun demikian, kejujuran profesional perlu disikapi dengan upaya meningkatkan profesionalitas. Untuk itu, pengembangan SDM ke arah profesional merupakan langkah strategis.

SDM yang melaksanakan profesinya berlandaskan profesionalisme memiliki kemampuan untuk menyelaraskan kemampuan dirinya dengan visi dan misi lembaga. Artinya, SDM tersebut akan mengaktualisasikan seluruh potensi yang ada dan mendayagunakannya dalam memberikan layanan kepada masyarakat, sehingga masyarakat merasakan manfaat dan mengakui keberadaannya.

\section{b Daya Kompetitif}

SDM yang memiliki daya kompetitif adalah mereka yang memiliki kemampuan ikut serta dalam persaingan. Apabila kita memandang bahwa melaksanakan tugas adalah suatu persaingan, maka SDM yang memiliki daya kompetitif adalah mereka yang dapat berfikir kreatif dan produktif. SDM yang berfikir kreatif dapat bersaing dan dapat memunculkan kreasi-kreasi baru. Berfikir kreatif dilandasi dengan kemampuan berfikir eksponensial dan mengeksplorasi berbagai komponen secara tekun dan ulet hingga menghasilkan suatu inovasi.

SDM yang inovatif tidak hanya terbatas pada kemampuan melaksanakan pekerjaan sesuai dengan tugasnya, melainkan kemampuan mencari dan menggunakan cara baru dalam menyelesaikan tugasnya tersebut. Sikap tekun dan ulet dalam melaksankan tugas hanya dapat menghasilkan prestasi temporer, sedangkan tekun dan ulet dalam berfikir kreatif akan menghasilkan pertasi berkelanjutan.

Salah satu sifat SDM yang inovatif adalah mereka yang tidak merasa puas dengan apa yang telah dikerjakan dan dihasilkannya, melainkan merasa penasaran atas kinerjanya. SDM yang inovatif hanya dapat dihasilkan melalui proses pengembangan kemampuan berfikir kreatif (creative thinking). Artinya, SDM yang memiliki daya kompetitif harus memiliki kecerdasan intelektual agar dapat memiliki banyak alternatif dalam memilih dan menentukan strategi yang tepat.

c Kompetensi fungsional 
Kompetensi adalah kemampuan yang dimiliki individu untuk melaksanakan profesinya. Sesungguhnya kompetensi tersebut merupakan suatu sistem pengetahuan yang terdiri atas pengetahuan konseptual, pengetahuan teknik, pengetahuan menyeleksi, dan pengetahuan memanfaatkan. Apabila seluruh pengetahuan tersebut diaktualisasikan secara simultan, maka manfaatnya dapat dirasakan baik oleh yang bersangkutan maupun oleh masayarakat.

Kompetensi pada tiga tataran pertama, yaitu kemampuan: konseptual, teknik, dan memutuskan merupakan kompetensi potensial. Sedangkan kompetensi pada tataran aplikasi tepat waktu dan tepat sasaran, itulah kompetensi fungsional. Kompetensi fungsional akan menunjukkan efektivitasnya manakala SDM memiliki motivasi yaitu motivasi intrinsik dan motivasi ekstrinsik. Motivasi intrinsik berkaitan erat dengan etos kerja, sedangkan motivasi ekstrinsik dapat berasal dari rekan kerja, lembaga, dan masyarakat.

SDM yang memiliki kompetensi fungsional adalah mereka yang memiliki kemampuan dalam mendayagunakan potensi diri (kompetensi potensial) yang disumbangkan (kemampuan mengaplikasikan secara tepat) dalam melaksanakan tugas atau profesinya. Untuk itu, pengembangan SDM bidang pendidikan dengan memberikan motivasi merupakan salah satu strategi yang dapat dipilih. Motivasi tersebut mungkin berupa posisi atau salary. Menurut Tilaar ( 1996: 343), pengembangan SDM selain meningkatkan kemampuan profesional juga meningkatkan posisi dan pendapatan.

d Keunggulan partisipatif

SDM unggul adalah SDM berkualitas yang memiliki kemampuan lebih dibandingkan dengan yang lainnya. Mereka dapat mengembangkan potensi diri dan sumber daya lainnya seoptimal mungkin. Dengan kemampuannya tersebut, SDM yang unggul dapat mencapai prestasi untuk kemajuan dirinya, lembaga, bangsa dan negara. Mereka yang memiliki keunggulan dapat survive dalam kehidupan yang kompetitif, karena mereka memiliki banyak pilihan dan kecerdasan untuk mengambil keputusan yang tepat. Terapat dua jenia SDM unggul, yaitu: keunggulan individualistik dan keunggulan partisipatoris.

SDM unggul secara individualistik adalah mereka yang memanfaatkan kemampuan dirinya untuk kepentingan pribadi. Hal ini sangat berbahaya, karena SDM yang unggul individualistik dapat melahirkan manusia tipe homo homini lupus. Sedangkan SDM unggul secara partisipatoris adalah mereka yang memiliki keunggulan dalam mengembangkan potensi diri untuk ikut berpartisipasi dalam kehidupan, baik yang bersifat kompetitif maupun kooperatif dan solidaritas sosial.

Dengan demikian, pengembangan SDM bidang pendidikan adalah upaya peningkatan kualitas SDM yang unggul partisipatoris. Untuk itu, sangat penting kecerdasan emosional dan kecerdasan intelektual dikembangkan secara terintegratif, karena akan menjadi kekuatan sinergis dalam melaksanakan tugas.

e Kerja Sama

Kemampuan kerja sama (teamwork) sangat penting di era globalisasi, karena dengan kemampuan tersebut akan menjadi kekuatan potensial bagi suatu 
organisasi atau institusi. Sesungguhnya, era globalisasi bersifat potensial yang menuntut kemampuan menyeleksi dan mendayagunakannya agar teraktualisasikan hingga bernilai guna. Salah satu upaya mengatualisasikan potensi tersebut adalah melalui kerja sama.

Namun demikian, aspek penting dalam proses seleksi dan memanfaatkan potensi tersebut adalah kemampuan menyelaraskannya dengan nilai-nilai indigeneous. Pada tataran praktis operasional, SDM yang memiliki nilai-nilai indigeneous tersebut adalah memahami visi dan misi lembaga, serta merefleksikannya dalam pelaksanaan tugas.

SDM yang memiliki kemampuan kerja sama harus diimbangi dengan kemampuan untuk mengembangkan jaringan-jaringan kerja sama (network). Pentingnya jaringan kerja sama dan kerja sama menjadi katalisator bagi tercapainya efektivitas dan efisiensi kerja. Kemampuan yang dibutuhkan dalam kerja sama adalah mengembangkan kemampuan untuk mengintegrasikan kemampuan diri dengan kemampuan mitra kerja terhadap orientasi kerja sama.

Untuk itu, pengembangan pada aspek dedikasi, disiplin, dan kejujuran sangat mutlak dalam suatu kerja sama, termasuk jujur terhadap kemampuan diri. Pentingnya sikap jujur dalam suatu kerja sama dikemukakan Fukuyama (1996), tanpa kejujuran tidak mungkin seseorang dapat melakukan bekerja sama dengan baik.

Pengembangan SDM bidang pendidikan pada domain ini adalah peningkatan kemampuan mencari jaringan kerja sama dan melaksanakan kerja sama dengan berlandasankan kepada dedikasi, disiplin, dan jujur serta moral-etis. Dengan demikian, SDM memiliki jati diri sesuai dengan visi dan misi lembaga.

Berdasarkan pada ilustrasi pengembangan SDM bidang pendidikan tersebut, maka dapat divisualisasikan sebagai berikut.

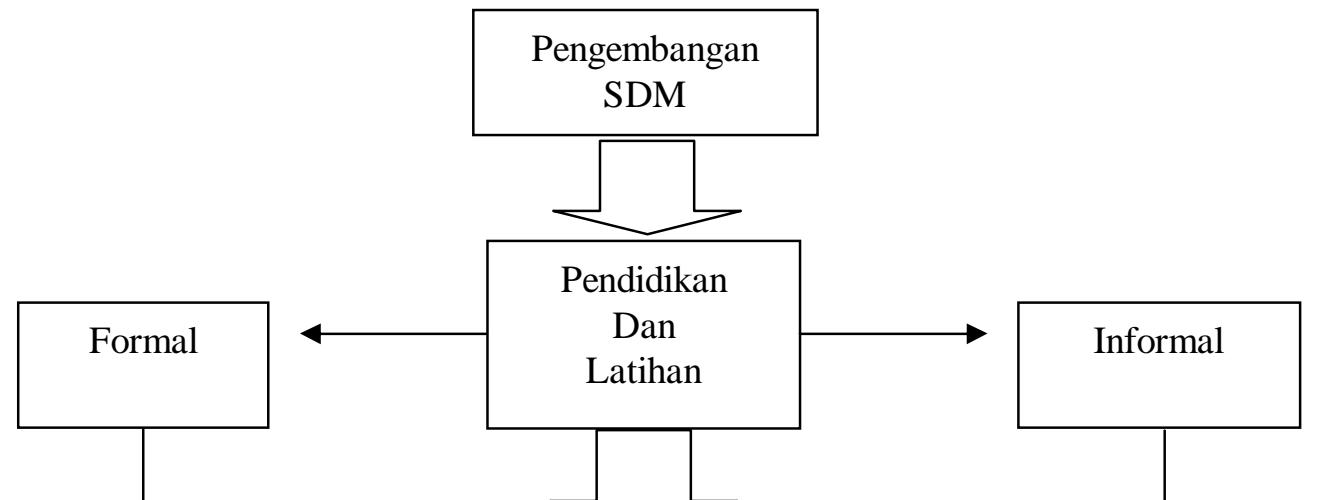




\section{Bagan 1: Model Pengembangan SDM}

Pengembangan SDM pada lima domain tersebut merupakan upaya mewujudkan SDM berkualitas untuk mempersiapkan masyarakat dan bangsa dalam menghadapi transformasi sosial yang kompetitif. Di mana pendidikan dan latihan menjadi wahana efektif bagi terwujudnya SDM berkualitas tersebut. Namun demikian, disinyalir banyak pihak bahwa pada tataran empiris, SDM yang telah melalui proses pendidikan dan latihan belum signifikan peningkatan kualitasnya.

Untuk itu, terhadap pengembangan SDM pada kelima domain di atas masih diperlukan upaya pengendalian mutu terpadu atau total quality control (TQC) dari pihak yang memiliki wewenang (authority), pada lembaga di mana SDM bertugas. Selain itu, pendidikan dan latihan sebagai wahana pengembangan SDM diperlukan suatu program diklat terpadu agar tercapai efektivitasnya.

Pengembangan SDM bidang pendidikan hendaknya tidak hanya sebatas pada peningkatan kemampuan untuk mempersiapkan masyarakat dalam mengikuti perubahan, melainkan lebih jauh ke depan adalah kemampuan mempersiapkan insan inovator bagi perubahan. SDM yang memiliki kemampuan tersebut menjadi aset strategis dalam merealisasikan peran pendidikan sebagai agent of innovation dan agent of changes. Selain itu, dapat menghasilkan insan-insan yang memiliki daya kompetitif yang tidak meninggalkan nilai-nilai indigeneous, sehingga mampu menunjukkan jati diri yang bermoral-etis dan identitas lembaga pada percaturan global.

\section{Penutup}


Peran penting pendidikan dalam pembangunan bangsa dengan jelas telah ditunjukkan secara yurudis formal dan praktik empiris operasional. SDM yang diperlukan dalam bidang pendidikan adalah SDM yang berkualitas dalam berfikir dan berbuat. Artinya, SDM yang menguasai IPTEK dan mengembangkannya sehingga mereka memiliki kemampuan secara konseptual dan kemampuan teknis yang dapat disumbangkan bagi peningkatan kualitas proses dan produk pendidikan. Untuk itu, sangat penting upaya pengembangan SDM agar dapat menunjukkan peran penting dan strategis pendidikan dalam transformasi sosial.

Pengembangan SDM adalah upaya peningkatan kualitas tenaga kependidikan, melalui pendidikan dan pelatihan. Terdapat dua jenis pengembangan SDM, yaitu pengembangan secara formal dan secara informal. Kedua jenis pengembangan SDM tersebut dalam kenyataannya tidak bersifat dikotomis, melainkan saling melengkapi sebagai suatu upaya peningkatan kualitas SDM. Terdapat lima domain penting dalam pengembangan SDM bidang pendidikan, yaitu: profesionalitas, daya kompetitif, kompetensi fungsional, keunggulan partisipatif, dan kerja sama. Pengembangan pada kelima domain tersebut diperlukan upaya pengendalian mutu terpadu atau total quality control (TQC). Selain itu, pendidikan dan latihan sebagai wahana pengembangan SDM diperlukan suatu program diklat terpadu agar tercapai efektivitasnya.

\section{Daftar Pustaka}

Fukuyama, F. 1996. Trust The Social Virtues and the Creation of Prosperity. London: Penguin Books.

Hasibuan, Malayu, S.P. 2007. Manajemen Sumber Daya Manusia. Jakarat: Bumi Aksara.

Sikula, Andrew, F. 1981. Personnel Administration and Human Resources Management. New York: A. Wiley Trans Ed. By John Wiley \& Sons Inc.

Tilaar, H.A.R. (1998). Beberapa Agenda Reformasi Pendidikan Nasional dalam Perspektif Abad 21. Magelang: Tera Indonesia.

UURI No. 20 Tahun 2003. Sistem Pendidikan Nasional. Bandung: Fokusmedia. 